\title{
Assessment of impacts of a potential sea-level rise on the coast of Montevideo, Uruguay
}

\author{
Andrés Saizar* \\ Uruguay Climate Change Country Study, Comisión Nacional sobre el Cambio Global, Ciudadela 1414 piso 6 , \\ 11100 Montevideo, Uruguay
}

\begin{abstract}
In this study, sea-level rise scenarios derived from a potential climate change were considered and the physical impacts on the coast of Montevideo, Uruguay, under each scenario were determined. The Bruun Rule was used to calculate coastal erosion. The impacts under a 'no action' response were first assessed. Land and coastal construction loss as well as the effects on infrastructure, such as the sewer system and the port, were evaluated. Inundation along the streams which discharge at the coast was qualitatively assessed. The associated costs were estimated. In addition, possible active responses were identified and their costs were estimated. Costs and benefits of each response option, including the 'no action' option, are discussed in the paper, concluding on the need for planning of anticipatory measures.
\end{abstract}

KEY WORDS: Sea-level rise Coastal erosion - Vulnerability · Adaptation - Bruun Rule - Río de la PIata . Montevideo

\section{INTRODUCTION}

The present study was carried out within the framework of the Uruguay Climate Change Country Study 'Assessment of Climate Change Impacts in Uruguay'. An analysis of the vulnerability of the Montevideo coastal area to sea-level rise, as well as of the possible adaptation measures, was performed.

Montevideo is the capital of the Republic of Uruguay. It hosts approximately $45 \%$ of the country's population. The most conspicuous residential areas are located within its coastal zone. Industries and services (e.g. oil refinery, port) are relatively heavily concentrated around Montevideo Bay.

Since its founding, the development of the city of Montevideo has involved the coast, both along the Río de la Plata and around Montevideo Bay. The location of the city's downtown and the expansion along the coast of suburbs which were originally summer resorts, such as Pocitos and Carrasco, is clear evidence of this.

\footnotetext{
•E-mail: asaizar@chasque.apc.org
}

The Rio de la Plata is a very large and complex fluviomarine system, where the water from the Paraná and Uruguay rivers mixes with the Atlantic Ocean water. Its total area, from Punta Gorda in the Departament of Colonia to the conventional border at the imaginary line between Punta del Este in Uruguay and Punta Rasa in Argentina, is $35000 \mathrm{~km}^{2}$ (MTOPPNUD-UNESCO 1979). The Río de la Plata is about $2 \mathrm{~km}$ wide at Punta Gorda and $220 \mathrm{~km}$ at its conventional border (CARP-IMFIA 1992). The water along the Montevideo coast is characterized by a high variability in salinity, between 0 and $33 \%$ (CARP-SHNSOHMA 1989).

From the geomorphologic standpoint, the Montevideo coast is formed by a series of beach arcs bounded by rocky headlands. The extension of the arcs is variable, ranging from beaches which may be classified as pocket beaches to long beach arcs having almost straight stretches. The names of the most important beaches and rocky headlands in Montevideo are indicated in Fig. 1.

Sand grain size at these beaches generally ranges from medium to fine. As is the general rule for the case 


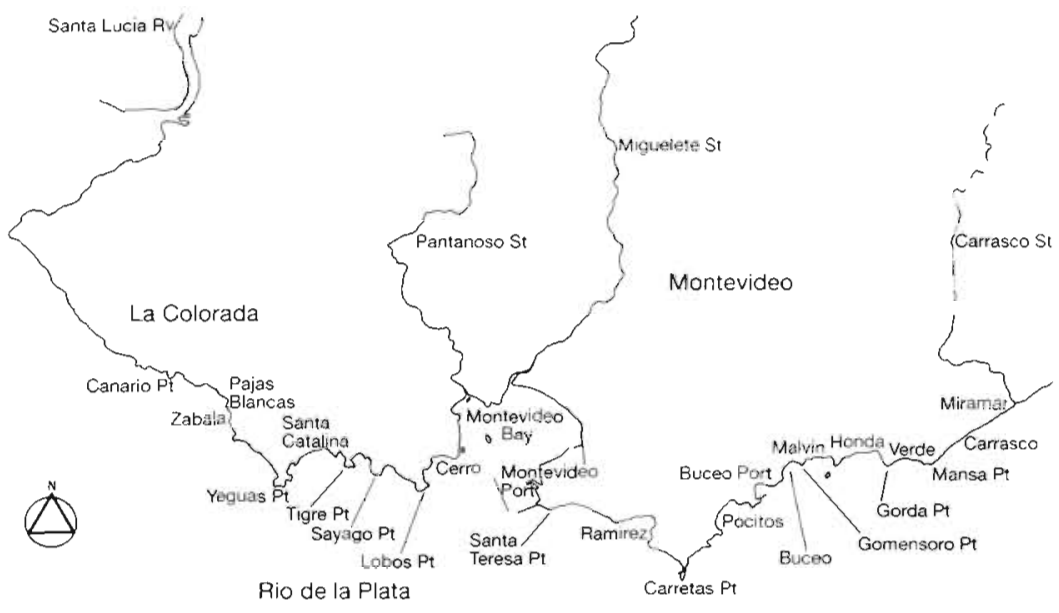

Fig. 1. Study area: beaches and rocky headlands (indicated by Pt). St: stream; Rv: river

on the fact that these beaches are protected by the rocky headlands, which are located relatively close to each other. Further, the urbanized areas are found farther than $150 \mathrm{~m}$ from the shoreline.

Thus, the values of land and building structures and the percentage of population affected by a potential sealevel rise may be significantly lower on the western beaches than on the rest of the coast. Therefore, this study focussed on the beaches located to the east of Montevideo Bay.

Santa Catalina beach, where sand mining takes place behind the foredune, deserves special comment. If the foredune is eroded, a sea-water intrusion of more than $200 \mathrm{~m}$ is likely

of arc beaches, it varies from relatively coarse at the end of the arc which is most exposed to the waves to relatively fine at the most protected end.

A remarkable characteristic of Río de la Plata hydrodynamics is the considerable influence of winds on the water level. The mean elevation in Montevideo is +0.91 m over the official datum for hydrographic purposes (mean of daily low waters), named the Wharton datum. The amplitude of the astronomic tide is about $0.40 \mathrm{~m}$ (SOHMA 1978). However, a mean sea level of $+2.50 \mathrm{~m}$ has a return period slightly over 1 yr. Storm surges are the cause of this fact, as well as of the highest recorded tide elevation in Montevideo $(+4.30 \mathrm{~m})$.

For the purposes of this analysis, the study area was restricted, as described below, to a portion of the coast of Montevideo Department. Further, only the direct effects of a potential sea-level rise were considered.

\section{METHODOLOGY}

\subsection{Study area}

Montevideo beaches can be divided into western and eastern beaches with respect to Montevideo Bay. Due to the high degree of pollution in the Bay and the presence of industries located nearby, there exist no beaches of importance for public use in this area.

The beaches to the west of the Bay are small arcs lying between rocky headlands. In fact, almost the entire coast between Montevideo Bay and the Santa Lucía River is formed by a rocky substrate on which small beach arcs, such as La Colorada and Santa Catalina, are found. The effects of sea-level rise in this area may a priori be considered tolerable. This is based to occur as a consequence of sand mining. This may cause the beach to become a pocket beach.

\subsection{Application of the Bruun Rule}

The Bruun Rule (Bruun 1962) was used to estimate the physical effects of a potential increase in mean sea level. In the case of sandy coasts, this model can be written as $R=S \times L / H$, where $R$ is the shoreline recession, $S$ is the mean sea-level rise, and $L / H$ is the ratio between the active profile width $(L)$ and the total active profile height $(H)$ measured from the active border of the dune to the depth of closure. The depth of closure may be defined as the seaward boundary of the crossshore active profile.

The Bruun Rule has been largely applied for the study of coastal vulnerability to sea-level rise (Nicholls et al. 1995). Although it has been questioned, it is one of the few models developed to address permanent modifications of mean sea level. In addition, using this model allows for comparing the results of this study with those obtained in other areas.

The main difficulty in using the Bruun Rule is the determination of the depth of closure. It is clear that this is a stochastic parameter, since every depth has an associated probability of behaving as the depth of closure. The $H$ value is also stochastic because it is a function of the depth of closure, and also of the active border of the dune, which in turn depends on the characteristics of the waves.

Two sea-level rise scenarios were selected for this study: $0.50 \mathrm{~m}$ and $1.0 \mathrm{~m}$. The $0.50 \mathrm{~m}$ value corresponds to the global sea-level rise estimate for approximately the year 2085, according to the best estimates, or for the year 2055 according to the highest estimates. The 
$1.0 \mathrm{~m}$ rise corresponds to the highest estimate for the year 2100 (IPCC 1990).

\subsection{Capital at risk}

The value of land and structures was obtained from real estate agents. Coastal areas are sought after for real estate investments due to their high value. Therefore, it will be assumed that the future scenario with regard to structures will consist of full development in coastal areas within the framework of the urban policies adopted for the city. It is thus foreseen that the areas where high rises already exist (basically 10-story buildings, constructed mostly between the 1960s and the present) will be saturated before the second half of the next century. It is also assumed that the areas where single-family residences predominate will retain this characteristic.

If adaptation measures are not implemented, sealevel rise will affect land, buildings and pavements. A projection of the their current values was performed in order to estimate their future values. The cost of pavements was estimated based on the costs of works currently in course in the same area. According to the judgement of 3 real estate agents who operate in the coastal area, the current market value of the constructions varies between US\$ 1100 and $1600 \mathrm{~m}^{-2}$, depending on the location. During the past $30 \mathrm{yr}$, trends have shown a doubling in price every 12 yr. These values have been corrected to account for the disruption caused by the macrodevaluation that occurred in 1982. Since this estimate results in very high values in 50 years' time, it will be assumed that the prices have a ceiling at twice the current value.

The costs of adaptation works were estimated on the basis of a preliminary concrete seawall design. Its cost was determined according to the unit price of concrete and a unit price of sand dredged for artificial beach nourishment (US\$ $5 \mathrm{~m}^{-3}$ ).

A $4 \%$ annual rate was used to update these values. This is the usual dollar devaluation rate for long periods of time.

\section{RESULTS: VULNERABILITY OF THE MONTEVIDEO COAST}

If the Bruun Rule is stated as $S / R=H / L$, an equivalence between 2 slopes, the shoreline recession slope (the ratio between sea-level rise and recession, $S / R$ ) and the mean slope of the active profile $(H / L)$, is implied.

Information on 4 beaches of the city, which are important both with regard to size and intensity of use, is provided in Fig. 2. These beaches are Playa Pocitos, Playa Malvín, Playa Honda and Playa Carrasco. The figure shows the plan view location of the profiles, as well as the cross-shore profiles of each beach and the $H / L$ ratio along each profile. It may be observed that, in every case, the $H / L$ value becomes fairly stable from a certain depth seawards. Thus, the coastal recession estimate is not significantly affected by uncertainty in the depth of closure. For this assessment it was assumed that the profile is affected up to an elevation of approximately $3.5 \mathrm{~m}$ over the Wharton datum. This implies that the slope value $H / L$ will remain the same even if the impact reaches higher elevations.

The assessment of climate-change-derived sea-level rise impacts by means of the method described carries a restriction. The Bruun Rule is based on the hypothesis that the beach profile is in equilibrium with the wave climate. Therefore, when using this method it is assumed that the wave climate does not change, which is a questionable assumption under a climate change situation. It is not possible to use Global Circulation Models (GCMs) to produce a preliminary assessment of wind variations in this area, since GCM outputs consist of mean values which would not provide information on storms. Substantial research is required to address this issue. For the purpose of this study, it is assumed that the storm regime does not vary, and the output may be considered as a baseline value.

The beaches studied are subject to different evolution processes. Although there is no historical information available to quantify this evolution it is assumed that, like on most beaches in the country, an erosion process takes place.

According to baseline assessments carried out during the Uruguay Climate Change Country Study, the mean sea-level historical variation from 1902 to the present is very small (less than $1 \mathrm{~mm} \mathrm{yr}^{-1}$ ) (E. Forbes \& R. Chao pers. comm.). Thus, it is not possible to relate the erosion process to variation in mean sea level.

Background experience indicates that the erosion process in Montevideo is of little significance. Further, it is masked by management practices carried out by the local municipality, both for beach cleaning ('raking') and for preventing the sand from blowing over the streets and obstructing the storm water sewers. The permeability of some of the rocky headlands to sediment transport also poses difficulties for assessing the equilibrium of a beach arc. For the purposes of this study, only the modification due to sea-level rise is considered. Erosion caused by other processes would thus add to it.

Beaches to the east of Montevideo Bay are the most used by the public. In the case of the 4 beaches studied, which are quite different from each other in their morphologic characteristics, the $H / L$ values which 


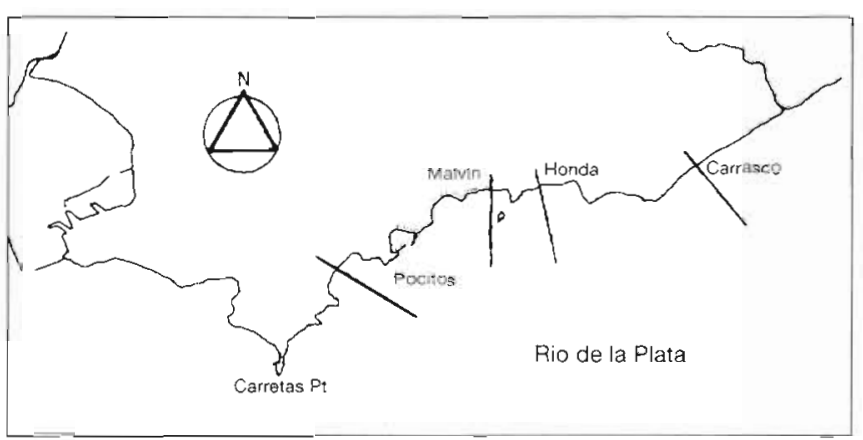

Fig. 2. Cross-shore profiles and $H / L$ ratio along the profiles

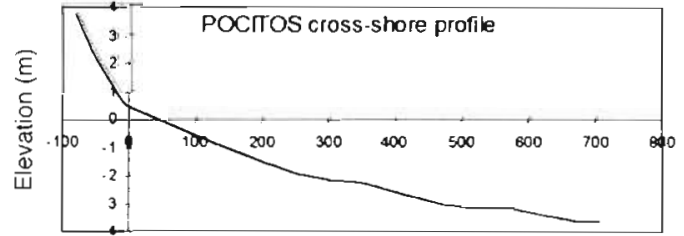

Distance from shoreline
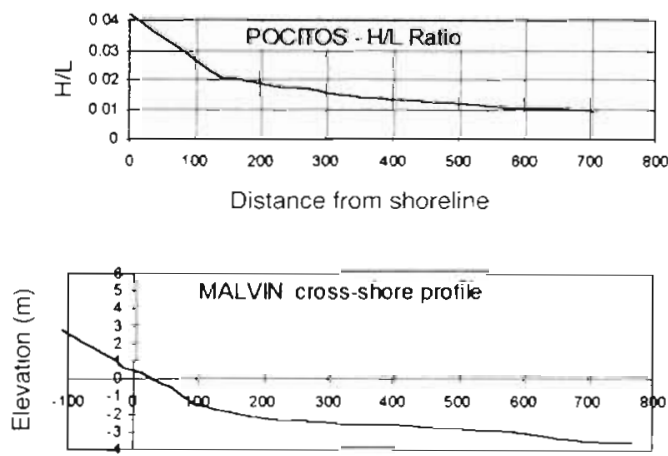

Distance from shoreline

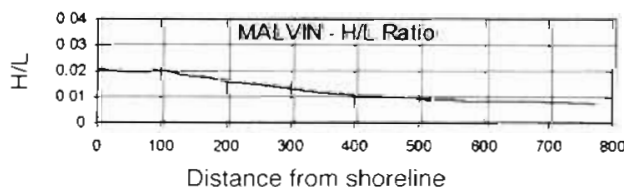

become reasonably stable in each case are:

$\begin{array}{llll}\text { Playa Pocitos } & 0.0096 & \text { Playa Malvín } & 0.0078 \\ \text { Playa Honda } & 0.0093 & \text { Playa Carrasco } & 0.0088\end{array}$

The mean value is 0.0089 , and the extreme deviations of this mean are +0.0007 and $-0.0011(+8 \%$ and $-12 \%$ ). Therefore, the error in using the $H / L$ mean value is very tolerable as compared to the uncertainties mentioned above, namely with regard to the evolution of the storm regime and the determination of the depth of closure. Thus the 0.0089 value will be used for all beaches located to the east of the Montevideo Bay

The shoreline recession value estimated using the $H / L=0.0089$ value is $56 \mathrm{~m}$ under a $0.50 \mathrm{~m}$ sea-level rise scenario, and $112 \mathrm{~m}$ under a $1.0 \mathrm{~m}$ sea-level rise.
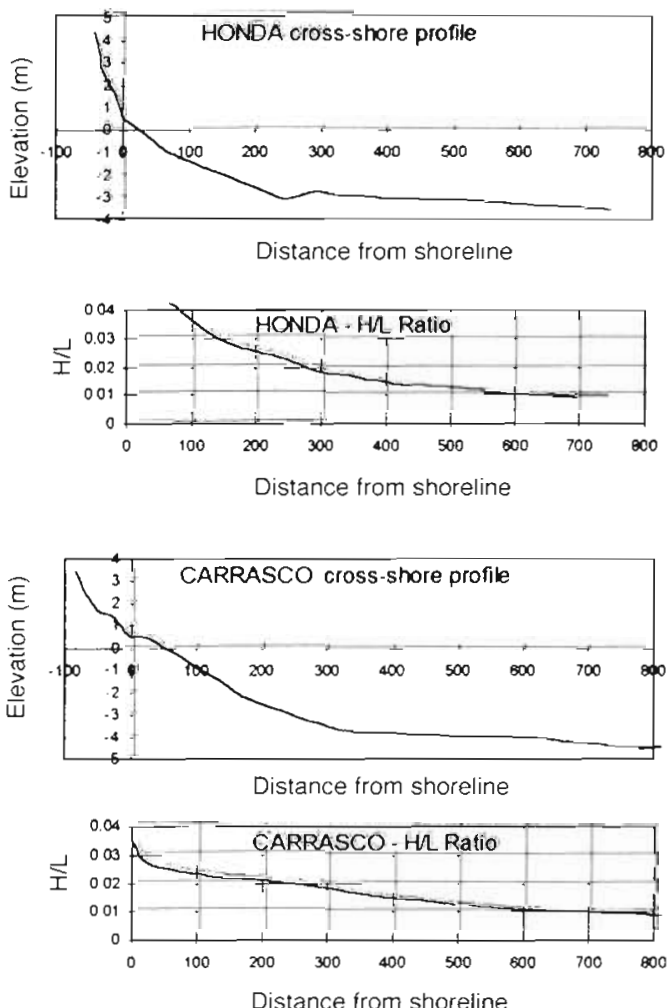

In order to assess the new location of the shoreline it was assumed that beaches would keep their arc shape. The 56 or $112 \mathrm{~m}$ recession would thus affect the central part of the beach arc. It was also assumed that a reduction in the width of the beach would occur. Under this condition, the recession of the dune line would be less than the 56 or $112 \mathrm{~m}$ shoreline recession. The impact on structures would thus be lower than if both recessions were alike.

The affected area and the value of structures under saturation conditions for each beach are shown in Table 1.

In addition to these values, the investment of about US\$ 100 million for the construction of the sewer system, completed at the end of 1996, should be taken into account. This value, projected $50 \mathrm{yr}$ into the future 
Table 1. Affected area (ha) and associated values (thousands of US\$) under each scenario. N/N = no name; $S$ : sea-level rise; Area: area outside the beach; Value: estimated future value of the area

\begin{tabular}{|c|c|c|c|c|}
\hline \multirow{2}{*}{$\begin{array}{l}\text { Rocky headlands } \\
\text { and beaches }\end{array}$} & \multicolumn{2}{|c|}{$S=0.50 \mathrm{~m}$} & \multicolumn{2}{|c|}{$S=1.0 \mathrm{~m}$} \\
\hline & Area & Value & Area & Value \\
\hline \multicolumn{5}{|l|}{ Punta Santa Teresa } \\
\hline \multicolumn{5}{|l|}{ Punta Brava } \\
\hline \multicolumn{5}{|l|}{ Punta Trouville } \\
\hline Playa Pocitos & 1.40 & 490 & 6.37 & 421600 \\
\hline \multicolumn{5}{|l|}{$\begin{array}{l}\text { Punta del Buceo } \\
\text { Puerto del Buceo }\end{array}$} \\
\hline \multicolumn{5}{|l|}{ Punta N/N } \\
\hline Playa Buceo & 1.05 & 368 & 2.10 & 735 \\
\hline \multicolumn{5}{|l|}{ Punta Gomensoro } \\
\hline Playa Malvín & - & & 1.50 & 66525 \\
\hline \multicolumn{5}{|l|}{ Punta del Descanso } \\
\hline Playa N/N & 0.50 & 175 & 1.50 & 36175 \\
\hline \multicolumn{5}{|l|}{ Punta N/N } \\
\hline Playa Honda & 1.50 & 525 & 4.00 & 60525 \\
\hline \multicolumn{5}{|l|}{ Punta N/N } \\
\hline Playa de Ingleses & - & & 0.20 & 70 \\
\hline \multicolumn{5}{|l|}{ Punta Gorda } \\
\hline Playa Verde & - & & 2.20 & 353 \\
\hline \multicolumn{5}{|l|}{ Punta N/N } \\
\hline Playa La Mulata & 0.40 & 140 & 1.20 & 142 \\
\hline \multicolumn{5}{|l|}{ Punta Mansa } \\
\hline Playa Carrasco & 1.95 & 21285 & 5.50 & 98645 \\
\hline Playa Miramar & - & & 6.00 & 2100 \\
\hline Total & 6.80 & 22983 & 29.07 & 627220 \\
\hline
\end{tabular}

with a $4 \%$ interest rate, results in a cost of about US\$ 700 million. Although the system is not likely to be entirely affected, some sectors of the pipeline which are very close to the beach would be damaged. Further, the system is composed of combined sewers, including weirs which drain the excess of storm water. Therefore, a rise in sea level would cause the intrusion of seawater into the system with a higher frequency than was assumed in the design conditions.

The operation of the port would not be affected under calm weather conditions. However, during storms the height of the docks is likely to be exceeded by the Rio de la Plata waters. During the highest flood tide recorded, which occurred in 1923, the water reached a level almost equal to the height of the dock.

In the sector of the city next to Montevideo Port, the elevation of the pavement is very similar to that of the Port docks. This downtown area is subject to inundation during the occurrence of heavy rain and high water levels in the Río de la Plata. This situation would be worsened under higher drainage level conditions.
Finally, the situation of the streams which drain both at Montevideo Bay and along the Río de la Plata coast, as well as the Santa Lucía River outlet, should be taken into account. Under a potential sea-level rise situation, the water level at the mouth of the streams which drain into the Bay would increase by $0.50 \mathrm{~m}$ or $1.0 \mathrm{~m}$, depending on the scenario involved. This higher water level would dissipate upstream, resulting in 2 possible effects. On the one hand, some lands which are currently not affected would become inundated, although with a relatively low frequency. On the other hand, the discharge of the storm water drainage system would be hindered. Sewers are designed for rain flows with return periods of $10 \mathrm{yr}$, assuming that drainage problems would occur with a low frequency. Under a sealevel rise condition this frequency would increase. In any case, quantification of the losses due to inundation should take into account that the land along the streams has a low cost.

The most important streams in the city which drain directly into the Río de la Plata are the Malvín and the Carrasco. Since the Malvín has casing along its lower course, an increase in water level at its mouth would only cause a moderate effect on the riverside lands due to an increased difficulty in storm water drainage. With regard to the Carrasco, the sector which flows within the most urbanized part of its basin, located to the south of the Camino Carrasco road, would have the capacity to handle the backwater that would be produced as a result of the stream discharging against a higher sea level. The remaining sector, to the north of Camino Carrasco, flows within a non-urbanized area which used to be a wetland until the 1970 s, when it was drained with channels. Some sectors of the former wetland area could be inundated again if an increase in the water level occurred.

The Santa Lucía River is the source of drinking water for the 'Montevideo system', supplying almost $50 \%$ of the country's population. The water intake is located in a reservoir, which would prevent enhanced salt intrusion as a result of a rise in mean sea level. Therefore, it is believed that drinking water supply would not be significantly affected. This situation would however change during periods in which the Santa Lucía flow is insufficient to satisfy water demand and it becomes necessary to place an additional intake downstream of the dam to fill the reservoir. Under such conditions, sea-level rise would cause the raw water to have a higher salinity level than usual.

\section{DISCUSSION: ADAPTATION TO SEA-LEVEL RISE}

Measures to adapt to climate change can be classified as follows: (0) 'no action', accepting the new shore- 
Table 2. Cost of the adaptation responses (in thousands of US\$). N/N: no name

\begin{tabular}{|c|c|c|c|c|}
\hline \multirow{2}{*}{$\begin{array}{l}\text { Rocky headlands } \\
\text { and beaches }\end{array}$} & \multicolumn{2}{|c|}{$S=0.50 \mathrm{~m}$} & \multicolumn{2}{|c|}{$S=1.0 \mathrm{~m}$} \\
\hline & $\begin{array}{l}\text { Sea- } \\
\text { wall }\end{array}$ & $\begin{array}{l}\text { Artificial } \\
\text { beach } \\
\text { maint. }\end{array}$ & $\begin{array}{l}\text { Sea- } \\
\text { wall }\end{array}$ & $\begin{array}{c}\text { Artificial } \\
\text { beach } \\
\text { maint. }\end{array}$ \\
\hline \multicolumn{5}{|l|}{ Punta Santa Teresa } \\
\hline Playa Ramirez & 2700 & 3177 & 3600 & 8000 \\
\hline \multicolumn{5}{|l|}{ Punta Brava } \\
\hline \multicolumn{5}{|l|}{ Punta Trouville } \\
\hline Playa Pocilos & 2100 & 8896 & 7200 & 22400 \\
\hline \multicolumn{5}{|l|}{ Punta del Buceo } \\
\hline \multicolumn{5}{|l|}{ Punta N/N } \\
\hline Playa Buceo & 6400 & 3812 & 8000 & 9600 \\
\hline \multicolumn{5}{|l|}{ Punta Gomensoro } \\
\hline Playa Malvín & - & 3892 & 2250 & 9800 \\
\hline \multicolumn{5}{|l|}{ Punta del Descanso } \\
\hline Playa N/N & 875 & 1390 & 1125 & 1750 \\
\hline \multicolumn{5}{|l|}{ Punta N/N } \\
\hline Playa Honda & 2100 & 3336 & 2700 & 4200 \\
\hline \multicolumn{5}{|l|}{ Punta N/N } \\
\hline Playa Ingleses & - & 397 & 600 & 1000 \\
\hline \multicolumn{5}{|l|}{ Punta Gorda } \\
\hline Playa Verde & - & 1589 & 1600 & 4000 \\
\hline \multicolumn{5}{|l|}{ Punta N/N } \\
\hline Playa La Mulata & 600 & 635 & 800 & 1271 \\
\hline \multicolumn{5}{|l|}{ Punta Mansa } \\
\hline Playa Carrasco & & & & \\
\hline Playa Miramar & 2275 & 22239 & 14000 & 56000 \\
\hline Total & 17050 & 49363 & 41875 & 118021 \\
\hline
\end{tabular}

line conditions; (1) protection of structures with seawalls, disregarding the beaches and the associated recreational use of the coast; and (2) protection of the beaches by artificial maintenance with sand, which would allow for their almost unchanged use.

The vulnerability analysis was performed on the basis of a 'no action' response, which means that no adaptation measures will be implemented. The cost of no action is similar to the cost of a planned retreat. A synthesis of the active responses further considered is presented below. For each specific case, the solution would actually imply a combination of the possible response measures. However, since this paper consists of a general analysis, only the 3 options mentioned above were taken into account.

The costs involved in option 0 are shown in Table 1 , while the costs of adaptation options 1 and 2 are presented in Table 2 .

The cost of the artificial beach maintenance option includes the cost of an initial maintenance phase to adapt to the new coastal profile, plus the subsequent maintenance cost. The required maintenance fre- quency is very variable and difficult to predict. However, for the purpose of this study, it is assumed that every 10 yr approximately $50 \%$ of the volume used in the initial maintenance phase should be added for further maintenance. This implies that over a $50 \mathrm{yr}$ period maintenance will cost 3.18 times the cost of the total beach volume.

If values addressed by options 1 and 2 are compared with those addressed by option 0 , it can be observed that for the $1.0 \mathrm{~m}$ sea-level rise scenario, the capital at risk is much higher than the cost of any of the responses. In the case of the $0.50 \mathrm{~m}$ scenario, the costs of beach maintenance exceed the value of structures at risk. This is to be expected, since it is a scenario with moderate erosion under which artificial maintenance is carried out over the entire active profile.

The cost associated with the loss of beach area is difficult to estimate. Nevertheless, it is important to take it into account at least qualitatively, since the construction of seawalls along the coast under these scenarios would imply a significant loss of beaches. In many cases the beach would be entirely lost.

A specific response could be selected in the case of each beach arc, with relative independence from the other beaches. However, it should be taken into account that the permeability of the rocky headlands is likely to affect the effectiveness of the artificial maintenance of a beach arc if the neighboring one is not maintained, as the latter might 'drain' part of the material supplied.

\section{CONCLUSIONS}

According to the assessment performed, the Montevideo coast is moderately sensitive to erosion that would be caused by a mean sea-level rise. The Montevideo coastal zone, which is mainly a residential area, is characterized by high occupancy and investment level. Therefore, even if erosion does not affect a very large area, the capital value at risk is significant. This has already been pointed out in a preliminary assessment of the entire coast of Uruguay (Volonté \& Nicholls 1994).

As previously stated, the application of the Bruun Rule carries a significant uncertainty. In spite of this it allows for assessing, in comparative terms, the problems associated with the potential erosion of the Montevideo coast and the effects of sea-level rise.

Given the long time span required for the implementation of policies affecting the coast (IPCC 1992), the adoption of anticipatory measures should be planned in advance. The options for adapting to climate change involve different costs and results. The decision on how much society is willing to pay for maintaining cer- 
tain conditions on the coast must be made through the corresponding political authorities. It should be pointed out that integrated coastal zone management necessarily requires the people's involvement in order to give strength to political decisions.

\section{LITERATURE CITED}

Bruun P (1962) Sea-level rise as a cause of shore erosion Journal of the Waterways and Harbors Division. Proc ASCE 88(WW1): 117-130

CARP-IMFIA (Comisión Administradora del Río de la PlataInstituto de Mecánica de los Fluídos e Ingeniería Ambiental, Facultad de Ingeniería, Universidad de la República) (1992) Corrientes y sedimentos en el Río de la Plata. CARP-IMFIA, Montevideo

CARP-SHN-SOHMA (Comisión Administradora del Río de la Plata-Servicio de Hidrografía Naval, Argentina-Servicio de Oceanografía, Hidrografía y Meteorología de la Armada, Uruguay) (1989) Estudio para la contaminación del Río de la Plata. CARP-SHN-SOHMA, Montevideo

IPCC (Intergovernmental Panel on Climate Change) (1990) Strategies for adaptation to sea-level rise. Misdorp $R$, Dronkers J, Spradley JR (eds) Response Strategies Work- ing Group, Coastal Zone Management Subgroup, Ministry of Transportation and Public Works, The Hague

IPCC (Intergovernmental Panel on Climate Change) (1992) Conference Statement of the International Workshop 'Global Climate Change and the Rising Challenge of the Sea' held on Margarita Island, Venezuela. Ministry of Transportation and Public Works, The Hague

MTOP-PNUD-UNESCO (Ministerio de Transporte y Obras Públicas, Uruguay-Programa de las Naciones Unidas para el Desarrollo-United Nations Education, Science and Culture Organization) (1979) Conservación y mejora de playas. Informe técnico del Proyecto URU/73/007, MTOPPNUD-UNESCO, Montevideo

Nicholls RJ, Leatherman SP, Dennis KC, Volonté CR (1995) Impacts and responses to sea-level rise: qualitative and quantitative assessments. J Coast Res Spec Iss 14:26-43

SOHMA (Servicio de Oceanografía, Hidrografía y Meteorología de la Armada) (1978) Observaciones Mareográficas, Puerto de Montevideo, Uruguay, Número 15:40. SOHMA, Montevideo

Volonté CR, Nicholls RJ (1994) The impacts of sea-level rise on the coastline of Uruguay. In: O'Callahan J (ed) Global climate change and the rising challenge of the sea. Proceedings of the IPCC workshop at Margarita Island, Venezuela, March 1992. US GPO: 1994-300-631/22606. NOAA, Silver Spring, MD, p 427-449 